\title{
Thirty Years of Economic Reform and Workforce Transformation in China
}

\section{Michel Cartier}

Translator. N. Jayaram

\section{Q OpenEdition \\ Journals}

\section{Electronic version}

URL: http://journals.openedition.org/chinaperspectives/5555

DOI: 10.4000/chinaperspectives.5555

ISSN: 1996-4617

\section{Publisher}

Centre d'étude français sur la Chine contemporaine

\section{Printed version}

Date of publication: 30 July 2011

Number of pages: 27-33

ISSN: 2070-3449

\section{Electronic reference}

Michel Cartier, "Thirty Years of Economic Reform and Workforce Transformation in China », China Perspectives [Online], 2011/2 | 2011, Online since 30 June 2014, connection on 28 October 2019. URL: http://journals.openedition.org/chinaperspectives/5555; DOI : 10.4000/chinaperspectives.5555 


\title{
Thirty Years of Economic Reform and
}

Workforce Transformation in China

\author{
MICHEL CARTIER*
}

\begin{abstract}
This study starts with the observation that Chinese publications on the workforce refer to two sets of statistics that diverge on a number of points: annual statistical reports take job status into account, while censuses adopt a double classification under branch and type of work. This study seeks to reconcile the two sets of figures to glean a more realistic image of changes in the situation over the last three decades. It shows that China has managed to create more than 250 million new jobs to deal with a difficult demographic situation characterised by major gaps between the expanding generation and the group leaving the workforce. However, after 30 years of reform, the job structure still resembles that of Japan in 1950, with nearly 50 percent of the active population engaged in the primary sector, 20 percent in the secondary sector, and 30 percent in the tertiary sector. There are more than 100 million surplus farmers. Moreover, newly created jobs come with far inferior social protections than in the pre-reform period.
\end{abstract}

KEYWORDS: Demographic transition, workforce, cities, countryside, employment structure, social protection

S uccessive economic reforms starting in 1979 have radically transformed China over the past 30 years. China's economy has emerged as the world's second largest after that of the United States and is set to take the top spot in the long run. Over these 30 years, China's development policies have changed in three phases. After spending the first half of this period pursuing a so-called "opening" (kaifang) policy centred on modernisation of production and technology transfers, China adopted a "socialist market economy" from 1992 with the focus on profitability and diversification of enterprises. This new policy gave rise to a system greatly resembling capitalism. Even before its entry into the World Trade Organisation in December 2001, China was encouraging foreign investment. Its development currently focuses on exporting manufactured products, benefiting from relocations by foreign firms investing in China, and from the price advantage China enjoys thanks to its undervalued currency. This article examines the consequences of this series of policies on the workforce.

\section{Demographic transition}

In the 1970s China entered the second phase of its demographic transition, characterised by declining birth and fertility rates. Birth control measures adopted from 1972 onwards helped reduce the birth rate from 33.6 per 1,000 women of childbearing age in 1970 to 17.27 per 1,000 in 1979, and the fertility rate from four to 2.5 children per woman. This trend was briefly interrupted during what is regarded as the "third baby boom" of the 1980s when, despite the adoption in 1979 of a radical one-child policy that failed to find favour with the people, the birth rate rose to 23 per 1,000 in 1987 , with the fertility rate declining only slightly to 2.2 children per woman in 1990. In fact, the authorities had anticipated this rise, having conceived of the one-child policy precisely in anticipation of the comingof-age of a multitude of young women born during the second baby boom of the 1960s. Simultaneous reductions in the birth and fertility rates re- sumed in the early 1990s following a renewed emphasis on the one-child policy and reinforced by a contraction in the number of young women coming of age, i.e., women born in the 1970 s. The birth rate had fallen to 14 per 1,000 by 2000 , with the fertility rate dropping to between 1.7 and 1.8 children per woman. The birth rate continued to decrease gradually in the 2000-2010 decade. It is now about 12 per 1,000, with the fertility rate appearing to hover around the same level.

This change has had several consequences. First of all, it has led to a modification in the age structure that has translated into a contraction in the proportion of young people under 15 years of age. Their proportion fell from 33.4 percent in 1982 to 24.3 percent in 2005 . At the same time, the 15-to-64 age group, often counted as the potentially active working population, grew by 300 million, from 624 million (61.9 percent) in 1982 to 927 million (71 percent) in 2005, representing an annual average growth of 13 million over the 23-year period. The 15-64 bracket will continue to grow at a gradual rate and reach a plateau at about a billion individuals by 2015 or so. That would account for 72.5 percent of the projected total population of 1.38 billion, following a sustained annual increase of 11.5 million for 33 consecutive years. As for those older than 65 , their number more than doubled in 23 years, from 49.3 million (4.9 percent) in 1982 to 100.5 million (7.5 percent) in 2005, and they are expected to account for about a quarter of the population between 2030 and 2040 .

\section{Workforce statistics}

It should be stressed at the outset that in contrast to population figures for the last three decades, which can be reconstituted with considerable precision on the basis of investigation and census data, there are large divergences between employment figures from the censuses and those cited

Michel Cartier is director of studies at l'École des hautes études en sciences sociales (Maison de l'Asie), Paris (Institute of Advances Studies in Social Sciences - Asia House): michel.cartier@ehess.fr. 
in annual official statistics. The first of these divergences is that census reports register the working population by place of residence and also include, for example, farmers living in municipal areas among the figures for the urban workforce. They then divide the workforce into two categories according to branch and type of work, but take no account of the legal status of the jobs. The annual statistical reports, in contrast, attach primacy to recording the legal status of jobs. Thus the reports list under "urban" workforce all those in public service, including a not insignificant number (officials and workers on state farms) stationed in the countryside. And they do not directly register farmers who returned to their family holdings following the dissolution of People's Communes after 1979, who thus appear implicitly after subtracting from the total rural workforce the employees of rural enterprises and the remainder of the non-farm private sector, and reintegrating the fraction of agricultural workers falling under the "urban" workforce category noted above. A second divergence concerns the total workforce. The annual reports during the 1980s showed workforce numbers notably lower than those from the censuses, and even though the two totals did coincide for a few years following the publication in 1993 of the 1990 census figures, the annual totals were higher than those in the census from the early 2000s. The third divergence concerns the major sectoral categories. In the overall accounts of these categories, the annual reports systematically underestimate the proportion of the primary sector, while overestimating that of the secondary and tertiary sectors. All these divergences will be borne in mind in the remainder of this article.

\section{Changes in the 1980s}

During the 1980s, the age structure was characterised by a very large difference between the sizes of the expanding and declining generations. The former included all those born between 1964 and 1974, numbering around 25 million individuals, while the declining generations covered all the Chinese turning 60 between 1980 and 1989, not more than 7 million individuals. It therefore became apparent that at least 16 million jobs needed to be created annually just to maintain an employment rate of 90 percent. Further, to the extent that, as in the Maoist era, workers' mobility between the countryside and cities remained highly constrained, the cities and the countryside constituted relatively autonomous zones, and in such conditions it would be preferable to look separately at the demographic situation in urban and rural areas.

To return to the 1982 census, cities and towns accounted for less than a fifth of the total population, and it may be deduced that the average size of the expanding urban generations would have oscillated around 4 million individuals, ${ }^{(1)}$ with the declining generations numbering no more than 1.2 million. To the extent that the state guaranteed full employment, it was necessary to create at least 2.5 million jobs annually to cope with the demographic situation, while also accommodating the millions of young people returning from the countryside after the end of the Cultural Revolution, (2) and the one million or so rural youth authorised to settle in cities every year. A total of 4 or 5 million jobs had to be created annually just to maintain full employment in urban areas.

The expanding generations in rural areas numbered some 20 million young people, replacing declining generations that were a mere 5 million strong. The situation was in fact a lot more difficult to fathom because, just as during the People's Commune era, the state was content with promot- ing the formation of rural enterprises, at first as part of cooperatives. As for farm labour, it was now entirely up to rural households to allocate tasks among their members to fit the needs of their small holdings. ${ }^{(3)}$

In 1980, going by the annual statistical report, the active urban workforce of 105 million made up 24 percent of the nation's total workforce and enjoyed a privileged position. In fact, apart from some 800,000 private workers (holdovers from what was still a sizeable sector in the 1950s), they were exclusively employed in the public sector (80.19 million) and urban collectives (24.25 million), which secured them several advantages encapsulated in the popular expression "Iron Rice Bowl." Given jobs after completing secondary or higher education, these wage earners (zhigong) spent their entire careers in the same branch of activity, even the same enterprise, which also defined their social environment. Employees of public or collective enterprises in urban areas enjoyed virtually free housing as well as health coverage. Women above 50 or 55 and men over 60 were entitled to a pension paid by their work unit equivalent to a high proportion of their salary. Their children were accorded priority access to jobs in their parents' work units or in a corresponding unit. The biggest enterprises ran schools and hospitals, and their managers had additional responsibility for family planning, all of which represented a heavy burden for the firms and their management.

For the sake of convenience, we will examine the decade in two equal periods separated by the urban reforms of 1985 .

During the first period (1980-1984), the urban workforce rose by 17.2 million, with 6.2 million in the public sector and 7.9 million in the urban collective sector. ${ }^{(4)}$ To this must be added 3 million private sector workers as well as those with the new status of employees of joint ventures between Chinese firms and foreign companies, generally located in the Special Economic Zones along the eastern and southern coast.

The creation of more than 17 million jobs over five years in the urban public and collective sectors imposed a very heavy burden on these enterprises, which as noted earlier also had to extend numerous benefits to their employees. Recruitment policies were modified starting with the urban reforms of 1985 , following which some 20 million new employees taken on in the years 1985-1989 were only accorded the title of "contract workers" with no immediate access to the basket of benefits under the "Iron Rice Bowl" system. Further, in order to lighten the burden represented by the construction and upkeep of housing, former workers were given the option of acquiring their homes on very favourable terms. Moreover, the government encouraged private sector development and the growth of new job outlets such as joint ventures or foreign direct investment by Hong Kong and Taiwan businesses. Their employee numbers rose by a total of 2.8 million in five years, from 5 million to 7.8 million. Nevertheless, in 1990, according to the 1991 statistical report, the urban workforce was made up almost exclusively of public and collective enterprise employees. However,

1. Urban populations had experienced a decline in fertility rates right from the 1960s, well before the launch of policies to restrict births.

2. The 1982 census noted 3.4 million "people awaiting employment," most of them young people under 25.

3. The great majority of farmers were subject to the so-called "household responsibility" system. They had the right only to use the land allocated to them according to household size and the number of potential workers. Their status was akin to that of tenant farmers: they had to hand over a portion of their production to the state at fixed prices but kept the surplus. Only a minority of "specialised households" enjoyed greater economic autonomy.

4. This situation was the result of a rebalancing in favour of the urban collective sector, which gained nearly 5 million workers in 1984, while the state sector shrank that same year by more than half a million, reverting to its 1982 level (86.3 million). 
Table 1 - Employment figures for 1980 to 1984 as per annual statistical reports (in millions)

\begin{tabular}{c|c|c|c|c|c|c|c|}
\hline Year & Urban employment & Public sector & Collective sector & Others & Rural employment & Non-agricultural & Total \\
\hline 1980 & 105.2 & 80.2 & 24.2 & 0.8 & 310.2 & 30 & 423 \\
\hline 1981 & 110.5 & 83.7 & 25.7 & 1.1 & 318.4 & 437.2 \\
\hline 1982 & 114.3 & 86.3 & 26.5 & 1.5 & 326.7 & 453 \\
\hline 1983 & 117.4 & 87.7 & 27.4 & 2.3 & 338.7 & 464.4 \\
\hline 1984 & 122.2 & 86.4 & 32.1 & 3.8 & 359.8 & 482 \\
\hline
\end{tabular}

Source: Annual Statistical Reports

Table 2 - Employment figures for 1985 to 1989 (in millions)

\begin{tabular}{c|c|c|c|c|c|c|c|}
\hline Year & Urban employment & Public sector & Collective sector & Others & Rural employment & Non-agricultural & Total \\
\hline 1980 & 123.6 & 89.9 & 32.2 & 5 & 370.6 & 37 & 498.7 \\
\hline 1985 & 128.1 & 93.3 & 34.2 & 5.4 & 379.9 & 512.8 \\
\hline 1986 & 132.1 & 96.5 & 34.9 & 6.4 & 390 & 527.8 \\
\hline 1987 & 136.1 & 99.8 & 35.3 & 7.5 & 400.7 & 543.3 \\
\hline 1988 & 137.4 & 101.1 & 35 & 7.8 & 409.4 & 553.3 \\
\hline
\end{tabular}

Source: Annual Statistical Reports

while the private sector was still weak, it had already gained visibility and begun to modify the urban physiognomy. ${ }^{(5)}$

\section{Rural workforce 1980 to 1990}

As for the countryside, rural enterprises saw massive expansion, the number of employees growing within one decade from 30 million to 92 million in 1990. To this should be added 16 million of the self-employed mainly engaged in trade. These new jobs would have accounted for 78 million people, more than three-fourths of the total growth (89 million, according to the annual reports), far short of the needs suggested by demographic parameters.

\section{Workforce changes as reflected in the 1982 and 1990 censuses}

The changes reflected in the annual statistical reports and in the 1982 and 1990 census data diverged considerably on many points. Going by the annual reports, the total workforce expanded by only 143.8 million, from 423.6 million in 1980 to 567.4 million in 1990, an annual increase of 13 million, divided into 35 million "urban" jobs and 110 million rural ones. These totals fall far short of the needs suggested by the demographic conditions. Meanwhile, the 1982 and 1990 censuses showed a total increase of 126 million in eight years, divided into 41 million urban and 75 million rural jobs, an annual average of 15.75 million in line with demographic parameters.

Moreover, rapid urbanisation had taken place during the eight years between the two censuses. The urban population (cities and towns) had expanded by nearly half, from 206 million to 296 million, an annual growth of 9 million, indicating a notable increase in the proportion of urbanites from 20 percent to 26 percent of China's population. Of course, this growth resulted essentially from the granting of municipal status to a large number of agglomerations ${ }^{(6)}$ alongside a still limited emigration from rural areas. In 1982, it may be noted, 27 million out of 113 million urban workers were engaged in agriculture, that is, 23 percent of the urban workforce.
As per the 1990 census, out of the 166 million urban workers, 60 million had the status of farmers and 37 million (22 percent) were engaged in agriculture. Meanwhile, the 52 million rural non-farm workers in 1990 still represented a mere 10.8 percent of the total, a figure and proportion much lower than the 108.7 million, or 22.8 percent, stated in annual reports.

\section{The 1990s}

As highlighted above, the demographic situation had turned much more favourable by the 1990s. Population growth had slowed, with the total rising from 1.14 billion in 1990 to 1.265 billion in 2000, an increase of 125 million (just under 11 percent in ten years). Over the same period, the potential working population expanded by just 105 million, from 755 million to 860 million, an average annual increase of 10.5 million. The ten expanding generations born between 1975 and 1985 totalled just 198 million, against 87 million for the generations exiting their working life. The pressure weakened compared to the previous decade, as it now became necessary to create just tens of millions of jobs annually. At the same time, as during the 1980s, there was strong urban growth. The population of cities and towns increased from 296 million to 455 million, that is, by 159 million, or more than 50 percent. Meanwhile the proportion of urbanites in China's population rose from 26 percent to 36 percent. As during the previous decade, this increase resulted from both the granting of municipality status to many agglomerations and a sharp influx of rural migrants, whose movements were no longer much restricted. The 2000 census noted change of residence by nearly 150 million people, about 50 million of them moving to another province. However, since these rural folk retained their "agricultural population" status, it had become possible to get an idea of the extent of the rural exodus. Given that in 2000, cities and towns had 160 million people with "agriculture status," while urban farmers numbered just 42 million, it is possible to gauge the extent of the "rural mi-

5. Such activities often lacked fixed locations. They were carried on wherever possible, often along the roadside (small family eateries) or underneath staircases.

6. The numbers rose from 244 cities and 2,660 towns in 1982 to 458 cities and 11,999 towns in 1990. 
Table 3 -Workforce changes 1990 to 1993 (in millions)

\begin{tabular}{c|c|c|c|c|c|c|c|c|}
\hline Year & Urban employment & Public sector & Collective sector & Others & Unidentified & Rural employment & Non agricole & Total \\
\hline 1990 & 170.4 & 103.5 & 36.6 & 14.4 & 20 & 477.1 & 108.6 & 647.4 \\
\hline 1991 & 174.6 & 106.6 & 36.2 & 7 & 20.3 & 480.3 & 113.4 & 654.9 \\
\hline 1992 & 178.6 & 108.9 & 36.2 & 11.1 & 20 & 482.9 & 124.8 & 661.5 \\
\hline 1993 & 182.6 & 109.2 & 33.9 & 16.3 & 23.2 & 485.5 & 145.1 & 668.1 \\
\hline
\end{tabular}

Source: Annual Statistical Reports

grant" (mingong) phenomenon. It should also be noted that the rural population shrank by 35 million between the two censuses.

It is possible to distinguish between three phases in the changing economic situation during the 1990 s.

\section{The 1991-1993 rebound}

These three years have to be considered a time of recovery following the political and social crisis of 1987-1989, which culminated in the occupation of Tiananmen Square in central Beijing in May 1989, leading to violent repression in early June. This crisis, going back to 1987, had economic, social, and political consequences. As for the economy, the period was characterised by a strong slowing down of growth (20 percent in three years) in the context of external trade deficit and currency devaluation. On the social level, popular dissatisfaction greeted price increases that reminded people of the galloping inflation of the late 1940s. In the political arena, the ruling class stood divided over popular demands for reform.

The first three years of the new decade were characterised by a return to growth. No doubt job creation was still limited. The active working population grew by a total of no more than 20.5 million, from 647.4 million to 668.1 million, (7) an annual growth of just under 7 million, much lower than during the previous decade. This growth was reflected prominently in urban areas, where 12 million jobs were created, the employment figure rising from 170 million to 182 million. In 1993, the 143 million secure jobs were divided between 109.2 million in the state sector (76 percent) and 33.9 million in the urban collectives (24 percent). Half of the new jobs were contractual. At the same time, there was a rise in the number of selfemployed, who numbered 11.1 million in the private sector ( 6 percent) and 6.2 million in enterprises of different kinds, including 3.5 million in foreign invested companies. It should also be noted that 23 million workers, or 12.6 percent of the total, were not clearly identified. ${ }^{(8)}$ The increase of 5.5 million state sector employees was compensated by the loss of 1.6 million jobs in the collective sector. The total of 143.1 million in these two categories represented a mere 78.3 percent of urban jobs: 29 million of them were contract workers (16 percent).

As for rural jobs, the total increased by just 4 million to 8.5 million - from 477 million to 481 million as per annual reports, but to 485.5 million according to the 1990 census. The novel element was the rapid development of rural enterprises and the private sector. In 1993, there were at least 123.5 million employees in rural enterprises and 22 million self-employed or private sector workers, or 30 percent of the rural workforce.

\section{The effect of ideological changes on employment}

As would have been expected, the years 1994-1997, following Deng Xiaoping's famous southern inspection tour of 1992, were characterised by a greater diversification in the types of enterprises and an encouragement of soaring foreign investment, initially from Hong Kong and Taiwan and then from developed countries as a whole. In 1997, urban jobs totalled 207.8 million, having expanded by 21.3 million in four years, an annual growth of 5.3 million. After growing by 3.4 million between 1993 and 1995, public sector jobs shrank by 2 million, accounting for just 110.4 million in 1997. As for the urban collective sector, it continued its slow decline from 1992 and supported only 28.8 million people, a contraction of 4 million in four years. The two sectors together thus employed 139.2 million people, or just 67 percent of the urban workforce. Private sector workers and the self-employed numbered a little over 25.4 million, or 12.2 percent of the urban workforce. As for enterprises of various kinds, they employed about 10 million or so, of whom 6 million worked in foreign invested firms. It is worth noting the persistent strength of jobs not clearly labelled - 23.6 million, a figure very close to that for 1990.

Rural jobs, meanwhile, increased by a mere 2.2 million, or just 0.45 percent. Non-agricultural jobs expanded slowly. The workforce of rural enterprises fluctuated, while the total of self-employed and those in the private sector stood at around 41 million after an increase of 13 million in three years. The 171 million non-farm workers represented a little over 35 percent of the rural workforce.

\section{The 1998 crisis and its consequences}

It is well known that the Asian financial crisis that gripped Southeast Asia in 1998 also badly affected South Korea, Taiwan, and Japan. But as will be shown, it also had serious consequences in China. Urban employment grew by just 15 million in three years, while the urban public and collective sectors, deemed unprofitable, slumped and lost 43.4 million jobs, or 36 percent of their workforce, from 1997 onward. In 2000, they employed 96 million people, accounting for just 42 percent of the urban workforce. In other sectors, employment expanded to 53.9 million, a gain of 5 million in three years. It is noteworthy that jobs not clearly identified increased from 57 million to 81.6 million, an increase of 24.6 million. This number is very close to the figure of 26.5 million unemployed, including 11 million who lost jobs and 15 million young people awaiting their first jobs, as noted in the 2000 census.

As regards the rural workforce that had practically stagnated at the 490 million level from 1993 onward, the Asian crisis had negligible effect, with only the non-agricultural sector contracting slightly to shed 2.4 million jobs, while the individual or self-employed sector lost about 10 million, or a third of the total.

7. The 1990 census figures used by the annual statistical reports from 1994

8. These "unidentified" workers emerged in 1990, when the total for "urban" labour had been reassessed at about 30 million in order to reconcile with the 1990 census data. The new total of 170.4 million was nevertheless slightly greater than the total working population in "cities" and "towns" - 166 million, including 38 million suburban farm workers. 
Table 4 - Workforce changes 1994 to 1997 (in millions)

\begin{tabular}{c|c|c|c|c|c|c|c|c|}
\hline Year & Urban employment & Public sector & Collective sector & Others & New forms & Rural employment & Non-agricultural & Total \\
\hline 1994 & 186.5 & 112.1 & 32.8 & 23.1 & 18.5 & 488 & 148.9 & 674.5 \\
\hline 1995 & 190.4 & 112.6 & 31.5 & 29.2 & 17.1 & 490.2 & 163.8 & 680.6 \\
\hline 1996 & 199.2 & 112.4 & 30.2 & 37.6 & 19 & 490.3 & 176 & 689.5 \\
\hline 1997 & 207.8 & 110.4 & 28.8 & 44.9 & 23.6 & 490.4 & 171 & 698.2 \\
\hline
\end{tabular}

Source : Annual Statistical Reports

Table 5 - Workforce changes 1998 to 2000 (in millions)

\begin{tabular}{c|c|c|c|c|c|c|c|c|}
\hline Year & Urban employment & Public sector & Collective sector & Others & New forms & Rural employment & Non-agricultural & Total \\
\hline 1998 & 216.2 & 90.6 & 19.6 & 49 & 57 & 490.4 & 171.3 & 706.4 \\
\hline 1999 & 224.1 & 85.7 & 17.1 & 52.9 & 68.4 & 489.8 & 166.1 & 713.9 \\
\hline 2000 & 231.5 & 81 & 15 & 53.9 & 81.6 & 489.3 & 168.9 & 720.8 \\
\hline
\end{tabular}

Source: Annual Statistical Reports

Taking the decade as a whole, in light of data from both the annual reports and the censuses of 1990 and 2000, it may be noted that the workforce grew by just 73 million in ten years, from 647.2 million to 720 million, or an average annual increase of 7.3 million. Meanwhile, there are major divergences depending upon whether data from the annual reports or the censuses are used. In the annual reports, this growth was reflected exclusively in urban employment, which grew by 62 million, that is, from 170 million to 231.5 million, or an annual increase of 5.2 million. Meanwhile, the urban public and collective sectors, which accounted for a total of 139 million jobs in 1990, had grown to 145 million in 1994, but slid steeply to 96 million in 2000, shrinking by a third. This fall was in part compensated by the development of new forms of employment, which accounted for the addition of 45 million jobs in ten years. But the fact that 81.6 million workers could not be properly identified was a sign of the difficulties China confronted in emerging from the crisis. As for the rural workforce, it grew by just a dozen or so million from the start of the decade, but its composition was modified nevertheless with the creation of some 60 million non-farm jobs. The proportion of non-agricultural workers grew by 50 percent, from 22 percent to 34 percent. It is important to note that in contrast to the experience of the 1980s, it was not just rural enterprises that contributed to transforming the employment structure: the strength of the private and self-employed sectors had grown 2.6 times over the decade - from 15 million in 1990 to 39 million in 2000. Again, as per the annual reports data, China in 1990 had 389 million engaged in the primary sector (60.1 percent), 138 million in the secondary sector, and 118 million (18.3 percent) in the tertiary sector. In 2000, the figures were 360 million (50 percent) in the primary sector, 162 million (22.5 percent) in the secondary sector, and 198 million (27.5 percent) in services.

The 1990 and 2000 census data confirm the sharp slowdown in workforce growth, with the total rising from 647.5 million to 720 million, (9) but they shed a different light on the employment structure. The primary sector stabilised around the 1990 figure, that is 467 million, but with a fall of 7 percentage points, from 72 percent to 65 percent, while the secondary and tertiary sectors soared from 97 million and 92 million to 108 million and 144 million, respectively, with the services sector speedily overtaking manufacturing. As was already the case in the 1982 census, the 1990 urban population included 39 million farmers (23 percent), while the active rural pop- ulation had 60 million people (12.5 percent) working in the secondary and tertiary sectors, and the 2000 census counted 46 million farmers.

\section{The 2000s}

The first years of the twenty-first century have been characterised by a sharp slowing down of demographic growth, which since 2000 has been around six per 1,000, or between 7 million and 8 million a year. At the same time, the potential working population has been growing by 12 million annually. This is because of the size differential between the ten expanding generations numbering 220 million individuals, and the declining generations of close to 100 million who were being replaced. The potential working population increased from 860 million in 2000 to 927 million in 2005, that is, an annual rise of 13.4 million. However, with young people joining the job queue later thanks to the prolongation of their studies, (10) and a trend towards letting more employees retire in their fifties, ${ }^{(11)}$ the authorities estimated at the start of the decade that they only needed to create 9 million jobs annually. The other major development was burgeoning urbanisation. Going by the annual reports, between 2000 and 2008 the total workforce expanded from 720.8 million to 774.8 million, an increase of 54 million or 6.75 million annually. Urbanisation proceeded apace. The 2000 census data and the 2005 study showed that China's urban population grew by 61 million, from 455 million to 516 million. In 2005, the urban population represented 40 percent of the country's total. As was the case since 1990, this increase was primarily due to migration from rural areas and the integration of a portion of farmers into the urban population. Rural exodus was to become the main cause of this growth henceforth. In 2005, some 325 million urban residents, that is, 62.5 percent of the total, retained "agricultural" status, although farm-related jobs in urban areas numbered no more than 77 million, a third of urban employment. Meanwhile, the rural population shed about 60 million, dropping to 744 million, or 57 percent of China's total.

9. The tables on jobs in the 2000 census resulted from a study of 118 million "long questionnaires," that is to say, just 9.5 percent of the total population. The figures cited here are restituted basing on the total of the annual reports for 2000, that is, 720.8 million. This figure included 26 million unemployed, including some 15 million young people awaiting their first job offers.

10. 40 percent of young people aged 16 to 19 years were studying in 2005 .

11. In 2005, of the 54 million retired people, 19 million, or 35 percent, were under 60 years old. 
Table 6 - Workforce changes 2001 to 2008 (in millions)

\begin{tabular}{c|c|c|c|c|c|c|c|c|}
\hline Year & Urban employment & Public sector & Collective sector & Others & New forms & Rural employment & Non-agricultural & Total \\
\hline 2001 & 239.4 & 76 & 12.9 & 53.9 & 106.5 & 489.3 & 169 & 730.2 \\
\hline 2002 & 247.8 & 71.6 & 11.2 & 73.9 & 91.1 & 490.8 & 169 & 737.4 \\
\hline 2003 & 256.4 & 68.8 & 10 & 80.8 & 96.8 & 489.6 & 177.9 & 744.3 \\
\hline 2004 & 264.8 & 67.1 & 9 & 97.8 & 90.9 & 487.9 & 179.5 & 752 \\
\hline 2005 & 264.8 & 64.9 & 8.1 & 96.9 & 103.4 & 485 & 183.6 & 758.2 \\
\hline 2006 & 283.1 & 64.3 & 7.6 & 112.6 & 106 & 480.1 & 194.6 & 764 \\
\hline 2007 & 293.5 & 64.2 & 7.2 & 125.5 & 96.2 & 476.1 & 199.5 & 769.9 \\
\hline 2008 & 302.1 & 64.5 & 6.6 & 135.9 & 95.1 & 472.7 & 203.6 & 774.8 \\
\hline
\end{tabular}

Source: Annual Statistical Reports

Annual statistical reports put China's workforce at 758.2 million in 2005, with an addition of 37.4 million in five years, or 7.5 million annually. This figure is contradicted by the mid-decade mini-census the same year, which noted a lower growth of 19.6 million or 3.9 million annually, going by the corrected figures of 694.8 million ${ }^{(12)}$ and 714.4 million. In the annual reports, the growth continued moderately, given that 774.8 million employed were noted at the end of 2008, an increase of 16.6 million in three years or 5.5 million annually. This growth was mainly reflected in urban employment, put at 302.1 million, having expanded by 70.6 million in 9 years, or an annual growth of 7.84 million. This was despite a contraction in the workforce of the urban public sector and collectives, which shed 25 million between 2000 and 2008, representing about 23.6 percent of urban employed. It might appear strange that at the same time, the number of jobs in traditionally defined categories rose by just 82 million, while those in new forms of activity rose by 81.6 million to 95.1 million. In 2008, they would have accounted for nearly a third of the urban workforce, a situation reflecting perhaps the spectacular influx of rural migrants and growth of the informal sector. Meanwhile, the annual reports noted just 8 or 9 million unemployed benefiting from support payments.

The situation in the countryside was simpler, given the diminishing population. The rural workforce lost 17 million between 2000 and 2008, shrinking from 489 million to 472 million. At the same time, the number of jobs created in rural enterprises and the private sector as well as the individual self-employed sector rose by 32 million to 203.6 million, meaning that 43 percent of rural inhabitants were no longer engaged in agriculture in 2008 .

\section{Conclusion}

\section{Modernisation}

It is clear that despite the relatively unfavourable demographic situation that prevailed until 1990, economic reforms had helped create a little more than 250 million jobs in 27 years, that is, more than 9 million annually. At the same time, the job structure underwent considerable modernisation, with a major shrinkage of the primary sector and development of the secondary and tertiary sectors.

However, as shown above, the amplitude of these transformations was reflected differently in census data and the annual reports. Going by census figures, the farming population at first increased from 348 million to 420 million and reached 468 million in 2000, eventually shrinking to 420 million in 2005, and its proportion falling from 73.7 percent to 59 percent. The secondary sector's workforce expanded from 81.8 million to 125 million, and that of the tertiary sector from 55 million to 168 million. In the annual reports, this modernisation was much more marked as the proportion of the primary sector workforce fell in 26 years from 68 percent to 39.6 percent, while those engaged in the secondary sector increased from 77 million in 1980 to 210 million in 2008, and those in the tertiary sector from 55 million to 257 million.

A glance at the census tables on the distribution of jobs by "types of activity" (zhiye), a classification of a sociological nature, helps better understand the extent of modernisation in Chinese society (table 8).

The 1982 census reported that political cadres made up 1.55 percent of the total workforce; technicians or those with technical or university education made up 5 percent; lower staff, a category made up of police officers and diverse groups of subordinate civil servants, made up 1.3 percent; trade and service employees 3.8 percent; agricultural workers 72 percent; and industrial producers and artisans 15.9 percent; while the 2005 minicensus recorded 1.5 percent political cadres, 7.5 percent technicians, 4 percent subordinate staff, 12 percent trade and service employees, 57 percent farm workers and 17.8 percent producers. ${ }^{(13)}$

The current structure is evidently much more modern than in 1982. Nevertheless it remains relatively archaic and close to the structures that prevailed in Japan, South Korea, or Taiwan 40 or 50 years ago.

\section{Increased insecurity}

The improved job qualification, as highlighted by the distribution of types of employment and the rise in educational levels, unfortunately emerged alongside increased insecurity for working people. As emphasised above, in the early 1980s, the "urban" workforce consisted of 99 percent of the salaried class (zhigong) in the public and collective sectors enjoying an "iron rice bowl," or a basket of privileges including lifetime employment, housing, medical coverage, and retirement at between 50 and 60 years of age. It has also been seen above that the main innovation between 1985 and 1990 was the creation of a contract employee status with no firm guarantee of employment for life. By the late 1990s, half of the 140 million employees enjoying job protection had disappeared, with the number of unemployed oscillating between 15 million and 20 million, of whom fewer

12. 720.8 million minus 26 million unemployed.

13. It should be stressed that the different categories in 2005 had much higher education levels than in 1982, especially in terms of those with diplomas or higher technical education. 
Table 7 - Proportion of working population by sector of activity according to annual statistical reports and census data (percentages)

\begin{tabular}{|c|c|c|c|c|}
\hline & Agriculture & Industry & Services & Total (in millions) \\
\hline Annul report 1980 & 68.7 & 18.3 & 13 & 423 \\
\hline Annual report 1982 & 68.1 & 18.4 & 13.5 & 453 \\
\hline Census 1982 & 73.7 & 15.7 & 10.6 & 521 \\
\hline Annual report 1990 & 60.1 & 21.4 & 18.3 & 647.5 \\
\hline Census 1990 & 70.8 & 15 & 14.2 & 647.5 \\
\hline Annual report 2000 & 50 & 22.5 & 27.5 & 720.8 \\
\hline Census 2000 & 65 & 15 & 20 & 720 \\
\hline Annual report 2005 & 44.8 & 23.7 & 31.3 & 758.2 \\
\hline Study of 2005 & 59 & 17.5 & 23.5 & 714 \\
\hline Annual report 2008 & 39.6 & 27.2 & 33.2 & 774.2 \\
\hline
\end{tabular}

Source: Annual Statistical Reports

Table 8 - Employment structure by type of activity (percentages)

\begin{tabular}{c|c|c|c|c|c|c|}
\hline Year & Cadres & Technicians & Lower-level staff & Services & Agriculturists & Producers \\
\hline 1982 & 1.55 & 5.1 & 1.3 & 4 & 72 & 16 \\
\hline 1990 & 1.7 & 5.3 & 1.75 & 5.4 & 70.5 & 15.1 \\
\hline 2000 & 1.7 & 5.7 & 3.1 & 9.2 & 64 & 16.3 \\
\hline 2005 & 1.5 & 7.5 & 4 & 12 & 57 & 17.8 \\
\hline
\end{tabular}

Source: Annual Statistical Reports

than half received the dole. More recent annual statistical reports show that the urban public and collective sectors employ no more than 71 million, or less than a tenth of China's workforce. Meanwhile, it should be stressed that the size of the new, ill-defined job categories is growing apace: it represented 95 million, or 12.2 percent of jobs, in 2008. A table inserted into the 2005 mini-census publication showed that out of 231 million workers (115 million, that is to say nearly two thirds, of urban workers, 52.9 million or nearly half of those in towns, and 58.7 million or 14 percent of workers in the countryside), just 20 percent enjoyed unemployment insurance, a third had old age insurance, and 41 percent had medical coverage. Moreover, among public sector employees, just 67 percent enjoyed unemployment insurance, 83 percent had retirement benefits, and 79 percent medical coverage. Of course, urban workers are relatively better protected in terms of old age and health ( 40 percent), while those in the countryside have to depend on their families. Add to this the rapid increase in the number of the self-employed and the private sector, whose employees are essentially dependent on insurance companies, as well as the burgeoning ranks of the unemployed, only a minority of whom receive any sort of allocations.

\section{Growing inequalities}

These changes exposed several weaknesses. The first is the relative strength of the farming class. Even if China were approaching the juncture where its potential working population would cease to grow after levelling out at about a billion workers around 2015, it would have to absorb the surplus farm labour estimated at a minimum of 100 million, and struggle with rising inequalities between provinces. There is much talk now of three Chinas: the industrialised coastal China; central China, where rural migrants originate; and an underdeveloped western China. A comparison of agricul- tural employment percentages in 1982 and 2008 suffices to understand the seriousness of the situation. Of course, the proportion of farm jobs has fallen in all provinces, but this reduction has varied greatly among regions. It has been strongest in places and provinces close to the coast Beijing, Tianjin, Hebei, Shandong, Jiangsu, Shanghai, Zhejiang, Fujian, and Guangdong), where more than 94 million secondary and tertiary jobs have been created. But progress has been much weaker in the central provinces (Shanxi, Anhui, Jiangxi, Henan, Hubei, Hunan, Sichuan, and Guangxi), which supply the vast majority of migrant workers. The total of secondary and tertiary sector jobs has grown by just 42 million in these provinces combined. Meanwhile, in the three northeastern provinces (Liaoning, Jilin, and Heilongjiang), which were highly industrialised in 1982 with a little over 50 percent of non-agricultural jobs (20.4 million out of 40.6 million), just 5 million secondary and tertiary jobs have been created, and the proportion of non-farm jobs has slid back to 44 percent. The rest, often referred to as western China, but including northwestern and southwestern provinces (Inner Mongolia, Shaanxi, Gansu, Qinghai, Ningxia, Xinjiang, Tibet, Guizhou, and Yunnan), created a mere 15.5 million non-agricultural jobs between 1982 and 2005. In 2005 these provinces had 28 percent of their workforce in secondary and tertiary jobs as against a massive 72 percent still bound to farming.

The recently published 2010 census findings show that China's population growth has slowed, with just 75 million added in 10 years. Nevertheless, the difference between the workforce of expanding and declining generations will continue to have an impact for at least another decade: the expanding generations to emerge between 2015 and 2020 will number 175 million and only then will begin to balance out the generations exiting the workforce.

I Translated by N. Jayaram 